\title{
Miranda
}

Revue pluridisciplinaire du monde anglophone /

Multidisciplinary peer-reviewed journal on the English-

speaking world

$12 \mid 2016$

Mapping gender. Old images ; new figures

\section{Producing a jazz album. An insider's perspective on Sarah Thorpe's Never Leave Me, Songs of Love and Longing}

Jean Szlamowicz

\section{OpenEdition}

\section{Journals}

Electronic version

URL: http://journals.openedition.org/miranda/8445

DOI: $10.4000 /$ miranda.8445

ISSN: 2108-6559

\section{Publisher}

Université Toulouse - Jean Jaurès

\section{Electronic reference}

Jean Szlamowicz, "Producing a jazz album. An insider's perspective on Sarah Thorpe's Never Leave Me, Songs of Love and Longing", Miranda [Online], 12 | 2016, Online since 01 March 2016, connection on 16 February 2021. URL: http://journals.openedition.org/miranda/8445 ; DOI: https://doi.org/10.4000/ miranda. 8445

This text was automatically generated on 16 February 2021.

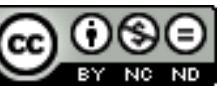

Miranda is licensed under a Creative Commons Attribution-NonCommercial-NoDerivatives 4.0

International License. 


\title{
Producing a jazz album. An insider's perspective on Sarah Thorpe's Never Leave Me, Songs of Love and Longing
}

\author{
Jean Szlamowicz
}

1 Sarah Thorpe's Never Leave Me, Songs of Love and Longing is a great album. I know because I helped produce it.

2 You might wonder how one goes about producing a jazz singer's first album. Paradoxically enough, despite the complexity and the uncertainties of the process, it's actually very simple.

3 Far from the hype of mass-produced music which requires an industrial approach to music-making-defining a marketing target, a genre, a formulaic sound-jazz musicians proceed with more intuition, not to mention purity of purpose. Typically, an album is the outgrowth of musicians playing together. Or conversely, as in this instance, it is a first step that enables the musicians to tour together.

4 The artistic process at work in jazz is based on individual impetus, not marketing planning. Very often, jazz musicians self-produce their albums. Relying on gut-feeling, a band leader will put together musicians he loves to play with, whose styles and personalities correspond to what he has in mind, write compositions and/or arrangements with those musicians in mind, rehearse and / or tour with them and then go into the studio. It is art born out of collective simpatico and independence of spirit.

5 Sometimes, the project stems not from the musicians but from someone who will become the de facto producer although this role can be limited to either financing or organising things.

6 What I was involved in was rather the artistic side of production. It consisted of discussing with the leader the choice of material and musicians, the aesthetic character of the project and its consistency. A producer is really a jazz lover who is able to voice an opinion. The producer should have open ears, not so much for technical questions, which are the musicians' realm (although it helps to know what's going on!), but for 
aesthetic matters. Choosing the personalities involved-and understanding the way they interact-is in fact the one true defining moment. From then on, everything should follow. Ideally, a well-produced album is thus one where the producer has nothing to do.

In this case, the goal of the album was to make a statement of personality. Sarah Thorpe has worked with legendary singer Michele Hendricks (daughter of Jon Hendricks, founding figure of scat singing and vocalese in the 50s') and French-based star Sara Lazarus. She has been playing for a while in various clubs in Paris. This implied singing in all sorts of places, with all sorts of musicians-and not always in ideal contexts (more on her at www.spiritofjazz.fr or www.sarah-thorpe.fr). At some point, this dues-paying musical journey enabled her to know what her own musical world was. For an album is (or should be) an artistic statement, the result of having something to say.

8 And so when she approached me with the idea of recording a full album, I became her artistic counsellor, suggesting songs and musicians, discussing the relevance of grooves and tempos, instruments and atmospheres-and more generally listening to her.

9 Sometimes artists do not perceive what makes them special. They often think they ought to do this or that, show their technical capacities, pander to the tastes of critics or the wishes of an elusive audience. A producer can be useful to say no to an idea that does not dovetail with the whole, no to a beautiful tune that has become hackneyed. A producer is here to make the musicians shine, to set forth what best becomes them. For sometimes, you may love a song but, like certain clothes that look good on the rack, it can fail to fit your personal style. Sometimes, you need someone from the outside to tell you how it fits.

10 Sarah Thorpe's album ended up being an easy affair. Her crystal-clear singing is at its best on ballads, soul-influenced grooves, and melody-driven compositions. She can interpret lyrics with poignancy. After long discussions, she selected songs that fit that description. Two forgotten rhythm and blues classics formerly sung by Nina Simone and Esther Philips in the 70s' ("I'm Gonna Leave You" and "Just Say Goodbye"), a rare jazz waltz ("Better Than Anything"), a standard with new lyrics and a radical change of mood ("Mack the Knife"), two contemporary songs by great vocalists (the swinger "Where Did't Go"? by Carmen Lundy and the forlorn rumba "Nowhere to Go" by Chilean singer Claudia Acuña), a funky poem by Michael Franks that needed beefing up ("Jive"), a heart-rending tune sung by Abbey Lincoln ("Never Leave Me"), a fresh samba with new lyrics ("Para Raio") and, lastly, a moving ballad ("The End of the Line").

The focus was to explore songs that had been neglected, sometimes never covered since the original recording.

The aesthetic agenda was also to find a form of narrative coherence. Hence the love theme that had to be addressed seriously, far from the mawkish take that is so often dominant with this theme (you might remember Denzel Washington singing "What the world needs now... is not another love song!" in Spike Lee's Mo' Better Blues).

Olivier Hutman, a gifted pianist with a ph.d in ethnology and music (under the direction of no less than Jean Rouch), tailored the songs to refresh them, to jazz up some of them and create a varied-but-not-motley ensemble. This was a primary concern about the material, which was dealt with in a very inspired fashion by all the musicians. Picking up the musicians was the initial choice that enabled the success of 
the recording-with musicians lacking experience or the required spirit, things can get corny in a minute.

Not so here. Philadelphian bassist and winner of the International Thelonious Monk Competition Darryl Hall has played with the greatest (singers Dianne Reeves, Carmen Lundy, Mary Stallings as well as Kenny Barron, Ravi Coltrane, Bireli Lagrene...). His beautiful sound and inescapable groove were essential. Philippe Soirat is the first-call drummer in France, because of his taste and musical understanding. Baltimore trumpet player Ronald Baker added another vital touch of bluesiness (Carmen McRae said it all: "Blues is to jazz what yeast is to bread. Without it, it stays flat") while Guillaume Naturel, again a first-call reedman, brought his colours and distinction.

In the studio, the fundamental role of a jazz producer is not to decide of anything, as the final cut is rather the outcome of discussions between the band-leader, the arranger and the musicians. His role is more to bring an outsider's perspective to the whole process, very much like a publisher. Contrary to pop and rock music, in jazz, a producer does not treat musicians like employees in the service of a product. The producer's attitude is one of restraint, above all considering the whole process as a way of letting the musicians do what they do best.

But there are many more ingredients. Paying careful attention to the artwork is crucial. It starts with good pictures. In this instance, jazz photographer Philippe Levy-Stab was called upon to deliver two soulful portraits.

I should also add the liner notes and the overall conception of the album as a consistent work of art. It is of foremost importance that the public understand that. A jazz album is not a random selection of bits and pieces to be downloaded absent-mindedly. It tells a story, not least that of its own conception.

It is important to be aware of the artistic efforts that go into making a recording and resist the consumer mentality that has become so prevalent in music. One should thus be reminded that the acquisition of an album is a glimpse into that collective endeavour, always a magical experience.

The album is available at www.spiritofjazz.fr

Sarah Thorpe : vocals

Olivier Hutman : piano, arrangements

Darryl Hall : bass

Philippe Soirat : drums

Ronald Baker : trumpet, flugelhorn

Guillaume Naturel : tenor sax, flute

1. Just Say Goodbye (Rodgers \& Ruth Grant)

2. Better Than Anything (David "Buck" Wheat \& Bill Loughborough)

3. Gonna Leave You (Nina Simone)

4. Mack The Knife (Kurt Weil \& Sarah Thorpe)

5. Where Did ' $T$ Go (Curtis Lundy \& Carmen Lundy)

6. Nowhere To Go (Claudia Acuna)

7. Jive (Michael Franks)

8. Never Leave Me (Gordon Jenkins)

9. Para Raio (Djavan \& Sarah Thorpe)

10. The End Of The Line (John Edmondson \& Cynthia Medley) 
INDEX

Subjects: Music

Keywords: singing, aesthetics, jazz, producer, voice

Mots-clés: chant, esthétique, jazz, producteur, voix

\section{AUTHORS}

\section{JEAN SZLAMOWICZ}

Professeur

Université de Bourgogne

slam.univ@orange.fr 